\section{АЛЬТЕРНАТИВНІ ДЖЕРЕЛА ЕНЕРГІї В ЗЕЛЕНОМУ ТУРИЗМІ}

\author{
ДЗІСЬ В.Г., \\ кандидат технічних наук, доцент \\ кафедри математики, фізики та \\ комп'ютерних технологій, \\ Вінницький національний \\ аграрний університет \\ (м. Вінниця)
}

У статті розглянуті перспективні напрямки розвитку зеленого туризму на Вінниччині. Описано низку надзвичайно унікальних та цікавих об'єктів, які маловідомі туристам. До них варто віднести «Іллінецьку астроблему» - кратери на місці падіння метеориту 400 млн. років тому. Кратери знаходиться між селами Іваньки Липовецького району та Лугова Іллінецького району. Вони виникли як результат падіння на Землю космічного тіла з приблизною вагою 40 млн т. Діаметр метеорита близько 230-300 м. У момент падіння метеорит розділився на 3 частини. У результаті з'явилося 13 кратерів. Найбільиі із них мають діаметри 7-10 км. На думку експертів, первісна глибина найбільшого кратера становила приблизно 800 м. Тутешні місия - свідки унікального явища планетарного масштабу $і$ є изікавими для туристичного бізнесу. Аналогів Іллінецькому кратеру немає у cвimi.

Проаналізовано проблеми вичерпності традиційних джерел енергї, та у зв'язку з цим неминуче зростання ціни на них. Доведено необхідність иирокого впровадження альтернативної енергетики у сфері зеленого сільського туризму. Перспективним $\epsilon$ застосування автономних, мережевих та гібридних сонячних напівпровідникових електричних станцій. Мережеві сонячні електричні станції як об'єкт сонячної енергетики можуть бути використані як для генерації електроенергї для власного споживання домогосподарства, так $і$ з метою подальшого продажу в загальнодержавну електромережу за зеленим тарифом.

Показано, щуо впровадження сонячнӧ̈ енергетики підприємствами туристичного бізнесу суттєво підвищує їхній прибуток та конкурентоспроможність, зменшує витрати на електроенергію, значно підвищує якість послуг, збільиує рівень туристичного сервісу на селі. Обгрунтовано необхідність державної підтримки та вкладення інвестицій у розвиток відновлювальних джерел енергї на селі та у зеленого сільського туризму.

Ключові слова: зелений сільський туризм, екотуризм, Іллінецький метеорит, енергетичний менеджмент, альтернативна енергетика, мережеві сонячні напівпровідникові електричні станції.

Табл.: 5. Рис.: 1. Літ.: 9.

\title{
ALTERNATIVE SOURCES OF ENERGY IN GREEN TOURISM
}

\author{
DZIS Victor, \\ Candidate of Technical Sciences, \\ Associate Professor, Department of Mathematics, \\ Physics and Computer Technologies, \\ Vinnytsia National Agrarian University
}


The article considers promising areas of green tourism development in Vinnytsia region. Describes a number of extremely unique and interesting objects that are little known to tourists. These include the "Illinets astroblem» - craters at the site of a meteorite fall 400 million years ago. The crater is located between the villages of Ivanky, Lypovets district and Luhovo, Illinets district. They arose as a result of the fall to Earth of a cosmic body with an approximate weight of 40 million tons. The diameter of the meteorite is about $230-300 \mathrm{~m}$. At the time of the fall, the meteorite was divided into 3 parts. As a result, 13 craters appeared. The largest of them have diameters of 7-10 km. According to experts, the initial depth of the largest crater was about $800 \mathrm{~m}$. The local places are witnesses of a unique phenomenon of planetary scale and are interesting for the tourist business. There are no analogues to Ilyinets Crater in the world.

The problems of exhaustion of traditional energy sources are analyzed, and in this connection the inevitable increase in their price. The necessity of wide introduction of alternative energy in the field of green rural tourism is proved. The use of autonomous, network and hybrid solar semiconductor power plants is. promising. Grid-connected solar power plants as an object of solar energy can be used both to generate electricity for household consumption and for the purpose of further sale to the national grid at a green tariff.

It is shown that the introduction of solar energy by tourism businesses significantly increases their profits and competitiveness, reduces electricity costs, significantly improves the quality of services, increases the level of tourist service in rural areas. The need for state support and investment for the development of renewable energy sources in rural areas and green rural tourism is substantiated.

Key words: green rural tourism, ecotourism, Illinetsky meteorite, energy management, alternative energy, network solar semiconductor electric power stations.

Tabl.: 5. Fig.: 1. Lit.: 9.

\title{
АЛЬТЕРНАТИВНЫЕ ИСТОЧНИКИ ЭНЕРГИИ В ЗЕЛЕНОМ ТУРИЗМЕ
}

\author{
ДЗИСь В.Г., \\ кандидат технических наук, доцент кафедры \\ математики, физики и компьютерных технологий, \\ Винницкий национальный аграрный университет
} (2. Винница)

В статье рассмотрены перспективные направления развития зеленого туризма Винницкой области. Описан ряд чрезвычайно уникальных и интересных объекте, которые малоизвестны туристам. К ним следует отнести «Ильинеикою астроблему» - кратеры на месте падения метеорита 400 млн. лет назад. Кратеры находится между сёлами Иваньки Липовецкого района и Луговая Ильинецкого района. Они возникли как результат падения на Землю космического тела примерной весом 40 млн. т. Диаметр метеорита около 230 - 300 м. В момент падения метеорит разделился на 3 части. В результате появилось 13 кратеров. Наибольшие из них имеют диаметры 7-10 км. По мнению экспертов, первоначальная глубина самого кратера составляла примерно 800 м. Здешние места - свидетели уникального явления планетарного масштаба и интересны для туристического бизнеса. Аналогов Ильинецкого кратера нет в мире. 
Проанализированы проблемы исчерпаемости традиционных источников энергии, и в связи с этим неизбежный рост цены на них. Доказана необходимость иирокого внедрения альтернативной энергетики в сфере зеленого сельского туризма. Перспективньл является применение автономных, сетевых и гибридных солнечных полупроводниковых электрических станиий. Сетевые солнечные электрические станциии как объект солнечной энергетики могут быть использованы как для генерации электроэнергии для собственного потребления домохозяйства, так и с иелью дальнейшей продажи в общегосударственную электросеть по зеленому тарифу.

Показано, что внедрение солнечной энергетики предприятиями туристического бизнеса существенно повышает их прибыль и конкурентоспособность, уменьшает затраты на электроэнергию, значительно повышает качество услуг, увеличивает уровень туристического сервиса на селе. Обоснована необходимость государственной поддержки и вложения инвестищий для развития возобновляемых источников энергии на селе и в зеленом сельском туризме.

Ключевые слова: зеленый сельский туризм, экотуризм, Иллинецкий метеорит, энергетический менеджмент, альтернативная энергетика, сетевые солнечные полупроводниковые электрические станции.

Табл.: 5. Рис.: 1. Лит.: 9.

Постановка проблеми. Для багатьох країн туризм є основним джерелом прибутків. У сфері туризму зайнятий кожний 10-й працівник. Щорічні надходження від туристичного бізнесу у світовому масштабі становлять понад 500 млрд доларів США. У світовій економіці туризм посідає третє місце після нафтовидобування та автомобілебудування. Значні прибутки отримують: США, країни Західної Свропи, деякі країни Азї, Африки та Латинської Америки.

Одним із перспективних напрямів розвитку туризму в Україні є «Зелений туризм». Він вирішує низку важливих проблем села: створює нові робочі місця, підвищує рівень доходів сільського населення, розвиває соціальну сферу, сприяє раціональному природокористуванню та охороні довкілля, збереженню історичних та культурних пам'яток.

Найбільшого економічного ефекту можна досягти впроваджуючи на підприємствах зеленого туризму сонячні напівпровідникові електричні станції. Вони дають можливість забезпечити підприємство дешевою електричною енергію, незалежність від зовнішніх постачальників, самостійно виробляти електроенергію та продавати іiі надлишок за «зеленим» тарифом у загальнодержавну електромережу.

Аналіз останніх досліджень та публікацій. Основні аспекти розвитку зеленого сільського та екологічного туризму знайшли відображення в роботах В. Бирковича [3], I. Власенко [4], П. Столярчука [5] та ін. Автори детально розглядають методичні, організаційні соціальні та економічні сторони зеленого туризму. Однак дискусійними залишаються питання енергетичного забезпечення об'єктів сільського зеленого туризму.

Формулювання цілей статті. Дослідити, як альтернативна енергетика може сприяти підвищенню економічної ефективності сільського зеленого та екологічного туризму. Надати практичні рекомендації, щодо використання сонячних напівпровідникових електричних станцій у сільському туризмі. 
Виклад основного матеріалу дослідження. У Вінницькій області послуги сільського зеленого туризму надають біля 30 сільських садиб та 15 баз екотуризму. На території області нараховується більше 4000 ставків та озер, протікає дві великі річки Південний Буг та Дністер, бере початок річка Рось, ростуть мальовничі ліси, що приваблює відвідувачів і $\epsilon$ важливою передумовою для розвитку сільського зеленого та екологічного туризму.

Найбільш активного розвитку сільського зеленого туризму у Вінницькій області зазнали Барський, Вінницький, Гайсинський, Немирівський, МогилівПодільський, Муровано-Куриловецький, Хмільницький та Ямпільський райони.

Важливо врахувати те, що переважна більшість послуг сільського зеленого туризму надається в межах особистого селянського господарства, а їхні доходи оподатковуються на загальних підставах як доходи фізичних осіб, не зареєстрованих як підприємці. Якщо такі послуги надаються за межами сільських садиб у спеціально збудованих приміщеннях (готелях, кемпінгах, базах відпочинку), то вони належать до сфери комерційної туристичної діяльності.

У Вінницькій області знаходиться низка надзвичайно унікальних та цікавих об'єктів, які маловідомі туристам. До них варто віднести «Ілінецьку астроблему» - кратери на місці падіння метеориту 400 млн років тому [1]. Кратери знаходяться між селами Іваньки Липовецького району та Лугова Іллінецького району. Вони виникли як результат падіння на Землю космічного тіла 3 приблизною вагою 40 млн т. Діаметр метеорита близько 230-300 м. У момент падіння метеорит розділився на 3 частини. У результаті з'явилося 13 кратерів. Найбільші з них мають діаметри 7-10 км. На думку експертів, первісна глибина найбільшого кратера становила приблизно 800 м. Температура в місці падіння метеорита підвищилась до $4000-5000^{\circ} \mathrm{C}$, а безпосередньо у місті контакту миттєва температура досягала $15000^{\circ} \mathrm{C}$. Місце падіння остигало 70-80 років. Тутешні місця - свідки унікального явища планетарного масштабу і $є$ цікавими для туристичного бізнесу. Аналогів Іллінецькому кратеру немає у світі.

В одному 3 кратерів поблизу села Лугова залишилися залишки каменоломень III-XII століть. Також поблизу Лугової на березі річки знайдено найбільший у світі агат розмірами $14,5 \times 25 \times 32$ см.

Другим важливим туристичним об'єктом села Іваньки є фортеця Акмалін (Білий Камінь). Фортеця була зруйнована навалою татар, залишився лише глибокий рів.

«Іллінецька астроблема» та фортеця Акмалін є свідками історичних епох, $\epsilon$ геологічною та історичною пам'ятками України і повинні охоронятися законом. У 2017 році частину території з кратерами площею 17,2 га оголошено геологічною пам'яткою природи, але значна частина земель території Іллінецького кратера приватизована і на них ведуться сільськогосподарські роботи.

Крім геологічних та історичних пам'яток, місцевість славиться мальовничою природою, лісами, має багато ставків та озер, неподалік 
протікають річки Соб та Сібок, що повинно сприяти розвитку екологічного туризму.

Унікальні дикі неосвоєні місця між селами Іваньки та Лугова, крім осель місцевих жителів, не мають елементарного спеціального облаштування для прийому туристів.

Хоча місцевість $є$ унікальною для Вінниччини, однак вона не має суттєвого туристичного значення. Найчастіші відвідувачі тут - групи дослідників, учених та одинокі групи туристів. Місцеві жителі навколишніх сіл намагаються розвивати зелений та екологічний туризм, але відсутність інфраструктури зводить їхні зусилля нанівець. Для розвитку «зеленого» сільського туризму необхідна державна підтримка селянських домогосподарств, дешеві кредити та вкладення інвестицій у туристичний бізнес на селі.

Інфраструктура сфери зеленого туризму України має цілу низку вагомих проблем, які гальмують розвиток туризму та ведення туристичного бізнесу.

$m$

$\stackrel{2}{2}$ оптимізації фінансових витрат.

Ефективним інструментом для підвищення конкурентоздатності підприємства, шляхом скорочення видатків на придбання енергетичних ресурсів $\epsilon$ енергетичний менеджмент. Він $є$ обов'язковим елементом у структурі підприємства зеленого туризму, яке поставило собі за мету скорочення споживання енергетичних ресурсів шляхом їхнього ефективного використання та впровадження альтернативних джерел енергії. 3-поміж усіх альтернативних джерел отримання енергії, сонячна енергетика $є$ найдешевшою, найбільш популярною.

При надані послуг зеленого туризму та створенні належного комфорту власники селянських осель несуть значні витрати на оплату за спожиту електричну енергію. Сучасні сільські оселі, що надають послуги зеленого туризму й укомплектовані повним набором побутової техніки, споживають 530 кВт год електроенергії на добу. Для такого будинку необхідно підвести потужність порядку 10-16 кВт, що дасть змогу покривати пікове добове навантаження. Місячне споживання електроенергії, у період туристичного сезону, складатиме 1500-9000 кВТ/год, а оплата за спожиту електроенергію 2500-15 000 грн. Вартість електричної енергії щорічно зростає. Це пояснюється 
вичерпністю традиційних джерел енергії, та у зв’язку 3 цим неминучим зростанням цін на них. Для зменшення витрат на електричну енергію необхідно впроваджувати альтернативні джерела енергії. Найбільший економічний ефект дають сонячні напівпровідникові електричні станції.

Провівши детальні розрахунки складових частин сонячної напівпровідникової електричної станції, можна не тільки значно скоротити розміри рахунків підприємства туристичного бізнесу за електричну енергію, але й отримати прибуток від продажу виробленої електричної енергії за зеленим тарифом. Крім усього іншого, сонячні напівпровідникові елементи сприяють збереженню стану екології, адже вони не викидають в атмосферу шкідливі речовин. На Вінниччині станом на 1 січня 2019 року працювали 38 сонячних електростанцій, сумарна встановлена потужність яких досягає 121 МВт, а у 2019 році заплановане будівництво 22 нових сонячних електростанцій сумарною потужністю до 100 МВт.

Ринок України переповнений пропозиціями щодо продажу сонячних напівпровідникових панелей та обладнання для сонячних електростанцій $[6,7,8$, 9] (табл. 1, 2).

Автономні сонячні електростанції (табл. 1) комплектуються акумуляторними батареями i дають можливість забезпечити безперервне живлення електроенергією споживача протягом доби.

Табличя 1

\section{Автономні сонячні напівпровідникові електричні станції}

\begin{tabular}{|c|c|c|c|}
\hline $\begin{array}{l}\text { Потужність, } \\
\text { кВт }\end{array}$ & $\begin{array}{l}\text { Орієнтована } \\
\text { вартість, } \\
\text { тис. грн. }\end{array}$ & $\begin{array}{l}\text { Резерв АКБ } \\
\text { при } 50 \% \\
\text { розряді, } \\
\text { кВт·год }\end{array}$ & Призначення \\
\hline 0,05 & 3,5 & 0,14 & $\begin{array}{l}\text { Переносна сонячна електростанція для туристичних походів, } \\
\text { риболовлі або відпочинку на природі. Можна під’єднати } \\
\text { освітлення, використовувати як зарядний пристрій для } \\
\text { ноутбука, телефона, планшета. }\end{array}$ \\
\hline 0,1 & 5,5 & 0,25 & $\begin{array}{l}\text { Переносна сонячна електростанція, потужності якої вистачить } \\
\text { для живлення ноутбука, переносного телевізора, мінімального } \\
\text { освітлення, підзарядки телефона, ліхтарика, планшета. }\end{array}$ \\
\hline $0,2-0,3$ & $14-17$ & $0,3-0,6$ & $\begin{array}{l}\text { Для перегляду телевізора, роботи переносного малопотужного } \\
\text { холодильника, освітлення і дрібної побутової техніки. }\end{array}$ \\
\hline $1-1,5$ & $20-40$ & 0,7 & $\begin{array}{l}\text { Безперервне живлення для не надто потужних електричних } \\
\text { приладів (для малопотужних водяних насосів, зарядки } \\
\text { мобільних телефонів, ноутбуків, телевізора, невеликого } \\
\text { холодильника, LED освітлення). У зимовий час лише потреби } \\
\text { LED освітлення та сигналізації. }\end{array}$ \\
\hline $2-3$ & $36-112$ & $1,2-2,4$ & $\begin{array}{l}\text { Може задовольнити всі } \text { найнеобхідніші потреби для } \\
\text { енергозабезпечення будинку } \\
\text { в період з березня по жовтень } \\
\text { потреби освітлення в зимовий час. }\end{array}$ \\
\hline $3-4$ & $47-120$ & $2,4-3,2$ & $\begin{array}{l}\text { Енергозабезпечення будинку та дачі в період з березня по } \\
\text { жовтень і потреби освітлення в зимовий час. }\end{array}$ \\
\hline $5-6$ & $112-318$ & $2,5-4,8$ & 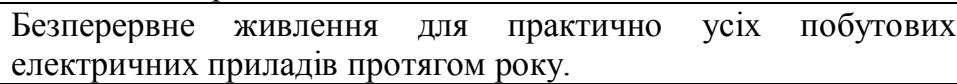 \\
\hline
\end{tabular}

Джерело: таблиия складена автором на основі $[6,7,8,9]$ 
Їх використовують для забезпечення електроенергією об'єктів, до яких технічно неможливо або економічно недоцільно підвести стаціонарну електромережу.

Таблиия 2

\section{Мережеві сонячні напівпровідникові електричні станції}

\begin{tabular}{|c|c|c|c|c|}
\hline $\begin{array}{c}\text { Потужність, } \\
\text { кВт }\end{array}$ & $\begin{array}{c}\text { Оріснтована } \\
\text { вартість, } \\
\text { тис. грн. }\end{array}$ & $\begin{array}{c}\text { Середня генерація } \\
\text { електренергії за } \\
\text { рік, } \\
\text { тис. кВт. год }\end{array}$ & $\begin{array}{c}\text { Прибуток від генерації } \\
\text { електроенергії за } \\
\text { «зеленим тарифом» } \\
\text { станом на 2019р., тис. } \\
\text { грн. }\end{array}$ & $\begin{array}{c}\text { Окупність при } \\
\text { мінімальному власному } \\
\text { споживанні, років }\end{array}$ \\
\hline 5 & $140-150$ & $5,6-6$ & $24-27$ & $5-5,6$ \\
\hline 10 & $167-210$ & $12-13$ & $56-60$ & $3,5-4$ \\
\hline 20 & $180-460$ & $21-25$ & $94-1122$ & $2,8-3,8$ \\
\hline 30 & $284-525$ & $29-35$ & $130-160$ & $2,5-3,5$ \\
\hline
\end{tabular}

Джерело: таблиия розроблена автором на основі $[6,7,8,9]$

Автономні сонячні електростанції доцільно застосовувати як резервне д) джерело живлення або для електричного забезпечення об'єктів, які значно віддалені від населених пунктів: будинків лісників, рибалок, баз екотуристів та будинків відпочинку на природі.

Найбільший попит серед сільського населення мають мережеві та гібридні електростанції потужністю до 30кВт (табл. 2).

Таблиия 3

Економічні показники роботи електричної станції потужністю 30 кВт за перший рік експлуатації при ставці зеленого тарифу 5,7336 грн/кВт• год (введеної в експлуатацію наприкінці 2018 року)

\begin{tabular}{|c|c|c|c|c|c|c|c|c|}
\hline \multirow[t]{2}{*}{ Місяць } & \multicolumn{3}{|c|}{ Електрична енергія } & \multirow[b]{2}{*}{$\begin{array}{c}\text { Дохід від } \\
\text { продажу } \\
\text { електри- } \\
\text { чної } \\
\text { енергії, } \\
\text { грн. }\end{array}$} & \multirow{2}{*}{$\begin{array}{c}\text { Податки, } \\
\text { грн. }\end{array}$} & \multirow{2}{*}{$\begin{array}{c}\text { Витрати } \\
\text { на } \\
\text { обслуго- } \\
\text { вування, } \\
\text { грн. }\end{array}$} & \multirow[b]{2}{*}{$\begin{array}{c}\text { Прибуток } \\
\text { від } \\
\text { генерації } \\
\text { електрич- } \\
\text { ної } \\
\text { енергії на } \\
\text { власні } \\
\text { потреби, } \\
\text { грн. }\end{array}$} & \multirow[b]{2}{*}{$\begin{array}{c}\text { Загальний } \\
\text { прибуток } \\
\text { від } \\
\text { генерації } \\
\text { електроене } \\
\text { ргії, грн. }\end{array}$} \\
\hline & $\begin{array}{c}\text { Генерація, } \\
\text { кВт· год }\end{array}$ & $\begin{array}{c}\text { Власне } \\
\text { спожи- } \\
\text { вання, } \\
\text { кВт· год }\end{array}$ & $\begin{array}{c}\text { Надлишок, } \\
\text { кВт· год }\end{array}$ & & & & & \\
\hline 1 & 810 & 200 & 610 & 3497 & 682 & 300 & 336 & 2887 \\
\hline 2 & 1260 & 200 & 1060 & 6078 & 1185 & 300 & 336 & 4964 \\
\hline 3 & 2700 & 200 & 2500 & 14334 & 2795 & 300 & 336 & 11611 \\
\hline 4 & 3400 & 200 & 3200 & 18348 & 3578 & 200 & 336 & 14942 \\
\hline 5 & 3980 & 500 & 3480 & 19953 & 3891 & 200 & 840 & 16792 \\
\hline 6 & 3940 & 1500 & 2440 & 13990 & 2728 & 200 & 2520 & 13852 \\
\hline 7 & 3930 & 1500 & 2430 & 13933 & 2717 & 200 & 2520 & 13806 \\
\hline 8 & 3880 & 1500 & 2380 & 13646 & 2661 & 200 & 2520 & 13575 \\
\hline 9 & 2900 & 600 & 2300 & 13187 & 2572 & 200 & 1008 & 11532 \\
\hline 10 & 2300 & 600 & 1700 & 9747 & 1901 & 200 & 1008 & 8762 \\
\hline 11 & 1180 & 300 & 880 & 5046 & 984 & 300 & 504 & 4320 \\
\hline 12 & 760 & 200 & 560 & 3211 & 626 & 300 & 336 & 657 \\
\hline За рік & 31040 & 7500 & 23540 & 134970 & 26320 & 2900 & 12600 & 119700 \\
\hline
\end{tabular}

Джерело: таблиия розроблена автором

Мережеві електричні станції дають можливість забезпечити домогосподарство електричною енергією у світлу пору доби, гібридні - 
цілодобово. Надлишок виробленої електричної енергії можна продавати державі за «зеленим» тарифом. Їх монтують на дахах будинків та господарських приміщень домогосподарств.

В Україні до кінця 2029 року зберігаються дуже сприятливі умови для приватних домогосподарств, які експлуатують сонячні напівпровідникові електричні станції та продають надлишок виробленої електричної енергії державі за «зеленим» тарифом, величина встановленої потужності яких не перевищує 30 кВт.

31 січня 2019 року Національна комісія, що здійснює державне регулювання у сфері енергетики (НКРЕКП) ввела у дію нові «зелені» тарифи для виробників електроенергії [1]. «Зелений» тариф на продаж електричної енергії, виробленої сонячними напівпровідниковими електричними станціями, залежить від дати введення станції у експлуатацію.

Оцінимо економічні показники при експлуатації сонячних мережевих електричних станцій потужністю 30 кВт введених у експлуатацію наприкінці 2018 року (табл. 3,4 ).

Оцінимо період повернення вкладених інвестицій (табл.5, рис.1).

При повних затратах 284-525 тис. грн. на введення в дію мережевої сонячної дахової електричної станції потужністю 30 кВт та власному щорічному споживанні 7500 кВт·год електричної енергії можна зробити такі висновки:

Таблиия 4

\section{Економічні показники роботи станції потужністю 30 кВт у перспективі на 11 років експлуатації}

(введеної в експлуатацію наприкінці 2018 року)

\begin{tabular}{|c|c|c|c|c|c|c|c|c|}
\hline \multirow[t]{2}{*}{ Рік } & \multicolumn{3}{|c|}{ Електрична енергія, кВт·год } & \multirow{2}{*}{$\begin{array}{c}\text { Дохід від } \\
\text { продажу } \\
\text { електричної } \\
\text { енергіiі, грн. }\end{array}$} & \multirow{2}{*}{$\begin{array}{c}\text { Податки, } \\
\text { грн. }\end{array}$} & \multirow{2}{*}{\begin{tabular}{|} 
Витрати на \\
обслуго- \\
вування, \\
грн.
\end{tabular}} & \multirow{2}{*}{$\begin{array}{c}\text { Прибуток } \\
\text { від } \\
\text { генерації } \\
\text { електричної } \\
\text { енергії на } \\
\text { власні } \\
\text { потреби, } \\
\text { грн. }\end{array}$} & \multirow{2}{*}{$\begin{array}{c}\text { Загальний } \\
\text { прибуток } \\
\text { від } \\
\text { генерації } \\
\text { електричної } \\
\text { енергії, грн. }\end{array}$} \\
\hline & $\begin{array}{c}\text { Генера- } \\
\text { ція }\end{array}$ & $\begin{array}{c}\text { Власне } \\
\text { спожива } \\
\text { ння }\end{array}$ & $\begin{array}{c}\text { Надли- } \\
\text { шок }\end{array}$ & & & & & \\
\hline 2019 & 31040 & 7500 & 23540 & 134969 & 26319 & 2900 & 12600 & 118350 \\
\hline 2220 & 31040 & 7500 & 23540 & 134969 & 26319 & 2900 & 12600 & 118350 \\
\hline 2021 & 31040 & 7500 & 23540 & 134969 & 26319 & 2900 & 12600 & 118350 \\
\hline 2022. & 31040 & 7500 & 23540 & 134969 & 26319 & 2900 & 12600 & 118350 \\
\hline 2023 & 30730 & 7500 & 23230 & 133192 & 25972 & 3100 & 12600 & 116719 \\
\hline 2024 & 30574 & 7500 & 23074 & 132297 & 25798 & 3300 & 12600 & 115799 \\
\hline 2025 & 30419 & 7500 & 22919 & 131408 & 25625 & 3500 & 12600 & 114884 \\
\hline 2026 & 29954 & 7500 & 22454 & 128742 & 25105 & 3700 & 12600 & 112538 \\
\hline 2027 & 29798 & 7500 & 22298 & 127848 & 24930 & 3900 & 12600 & 111617 \\
\hline 2028 & 29643 & 7500 & 22143 & 126959 & 24757 & 4000 & 12600 & 110802 \\
\hline 2029 & 29488 & 7500 & 21988 & 126070 & 24584 & 4100 & 12600 & 109987 \\
\hline $\begin{array}{c}\text { Всьо } \\
\text { го }\end{array}$ & 334766 & 82500 & 252266 & 1446392 & 282047 & 37200 & 138600 & 1265746 \\
\hline
\end{tabular}

Джерело: таблиия розроблена автором

для електростанції введеної в експлуатацію на початку 2019 року вкладені 
інвестиції повертаються протягом 2,2-4,2 років, за 11 років експлуатації прибуток складе 740-981 тис. грн., середній за рік - 67-89 тис. грн.;

Таблиия 5

\section{Плановий прибуток від генерації електроенергії сонячними} напівпровідниковими електростанція потужністю 30 кВт на період експлуатації до кінця 2029 року

\begin{tabular}{|c|c|c|c|c|c|c|c|c|c|c|}
\hline \multirow{4}{*}{$\begin{array}{c}\text { Рік } \\
\text { введе- } \\
\text { ння в } \\
\text { експлуат } \\
\text { ацію. } \\
\text { «Зеленн } \\
\text { ий» } \\
\text { тариф, } \\
\text { грн/кВт. } \\
\text { год }\end{array}$} & \multicolumn{3}{|c|}{$\begin{array}{c}\text { Електрична енергія, } \\
\text { кВт·год }\end{array}$} & \multirow{3}{*}{$\begin{array}{l}\text { Дохід } \\
\text { від } \\
\text { продажу } \\
\text { електро- } \\
\text { енергії }\end{array}$} & \multirow[t]{3}{*}{$\begin{array}{c}\text { Подат- } \\
\text { ки }\end{array}$} & \multirow{3}{*}{$\begin{array}{c}\text { Витра- } \\
\text { ти на } \\
\text { обслу- } \\
\text { говува } \\
\text { ння } \\
\text { станції }\end{array}$} & \multirow{3}{*}{$\begin{array}{c}\text { Прибуток } \\
\text { від } \\
\text { генерації } \\
\text { електрое } \\
\text { нергії на } \\
\text { власні } \\
\text { потреби }\end{array}$} & \multirow{3}{*}{$\begin{array}{c}\text { Загаль } \\
\text { ний } \\
\text { прибут } \\
\text { ок від } \\
\text { генера } \\
\text { ції } \\
\text { електр } \\
\text { ичної } \\
\text { енергії }\end{array}$} & \multirow{2}{*}{\multicolumn{2}{|c|}{$\begin{array}{c}\text { Загальний } \\
\text { прибуток } \\
\text { від експлуатації } \\
\text { станції }\end{array}$}} \\
\hline & \multirow[t]{3}{*}{$\begin{array}{l}\text { Гене- } \\
\text { рація }\end{array}$} & \multirow{3}{*}{$\begin{array}{c}\text { Власне } \\
\text { спожи- } \\
\text { вання }\end{array}$} & \multirow[t]{3}{*}{$\begin{array}{c}\text { Надли- } \\
\text { шок }\end{array}$} & & & & & & & \\
\hline & & & & & & & & & $\begin{array}{c}\text { Вартіс } \\
\text { ть } \\
\text { станції } \\
284000 \\
\text { грн. }\end{array}$ & $\begin{array}{c}\text { Вартість } \\
\text { станції } \\
525000 \\
\text { грн. }\end{array}$ \\
\hline & & & & \multicolumn{5}{|c|}{ Грн. } & & \\
\hline $\begin{array}{l}01.01 .19 \\
5,7336\end{array}$ & 334766 & 82500 & 252266 & 1446392 & 282047 & 37200 & 138600 & 1265746 & 981745 & 740746 \\
\hline $\begin{array}{l}01.01 .20 \\
5,1534 \\
\end{array}$ & 305278 & 75000 & 230278 & 1186715 & 231409 & 33100 & 126000 & 1048205 & 764205 & 523205 \\
\hline $\begin{array}{l}01.01 .25 \\
4,5903\end{array}$ & 154890 & 37500 & 117390 & 538855 & 105077 & 14700 & 63000 & 482079 & 198079 & -42921 \\
\hline
\end{tabular}

\section{Джерело: таблиия розроблена автором}

для електростанції введеної в експлуатацію на початку 2020 року вкладені інвестиції повертаються протягом $2,8-5,0$ років, за 10 років експлуатації прибуток складе 523-764 тис. грн., середній за рік - 52-76 тис. грн.;

- для електростанції вартістю 284 тис. грн. введеної в експлуатацію на початку 2025 року вкладені інвестиції повертаються протягом 3,0-3,3 роки, за 5 років експлуатації прибуток складе 198 тис. грн., середній за рік - 39,5 тис. грн. Робота станції вартістю 525 тис. буде збитковою.

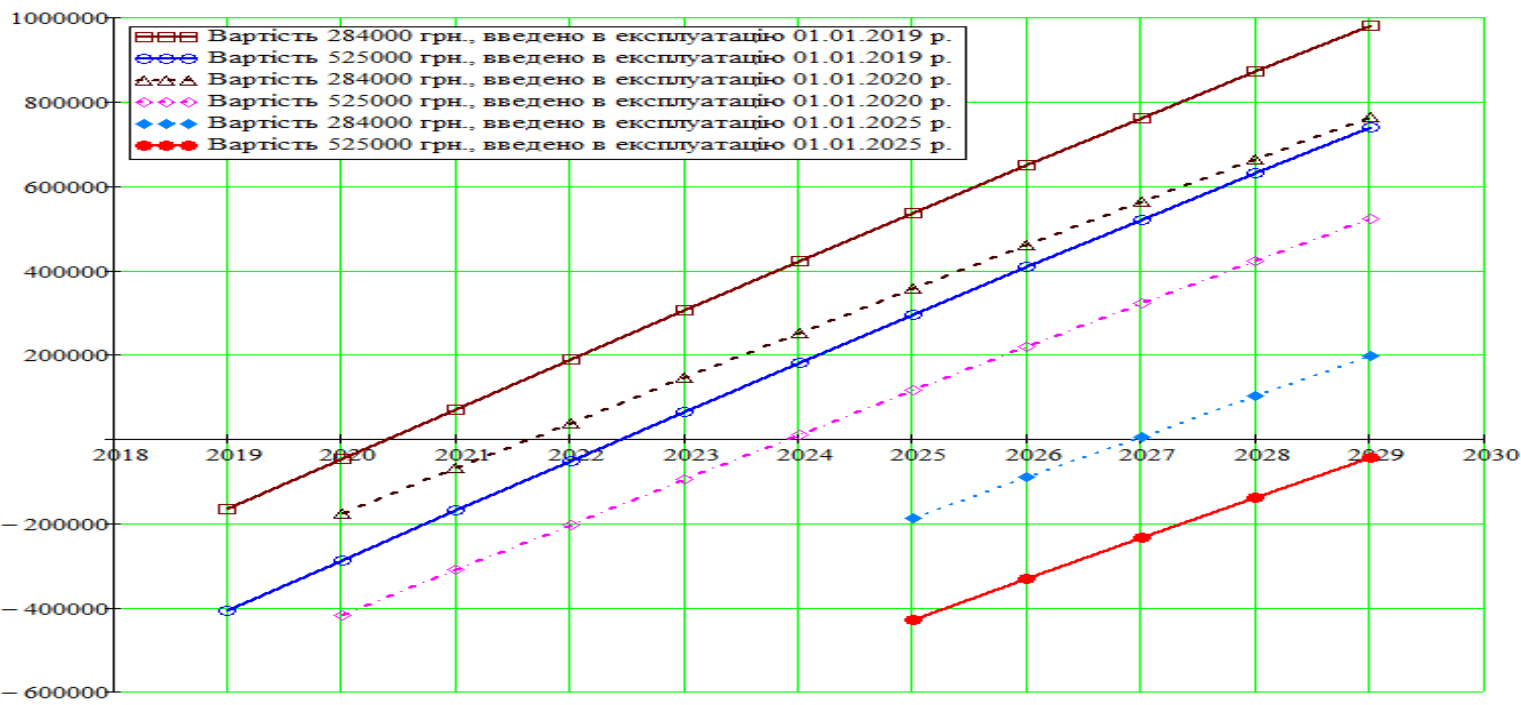

Рис. 1. Повернення вкладених інвестицій

Джерело: рисунок розроблено автором 
Отже, можна зрозуміти, що «зелена» енергетика економічно ефективна та дійсно корисна для екології і посідає важливе місце у майбутньому людства. Але крім цього, вона також вигідна й виробникам відновлюваної енергії, а особливо — власникам сонячних електростанцій.

Висновки. У Вінницькій області $€$ низка унікальних об'єктів, які маловідомі туристам. До них варто віднести Іллінецький кратер. У майбутньому він може бути популярним як для внутрішніх, так і для зовнішніх туристів, але для цього потрібно відновити інфраструктуру навколишніх сіл та залучити інвестиції для організації туристичного бізнесу.

Доцільно для забезпечення безперебійного електропостачання об'єктів зеленого сільського та екологічного туризму впроваджувати альтернативні відновлювані джерела електроенергії. Упровадження в сільський зелений та екологічний туризм сонячних напівпровідникових електричних станцій дає можливість: забезпечити безперебійне електричне живлення сільського домогосподарства, об’єктів сільського зеленого туризму та екологічного туризму; отримати додатковий прибуток від продажу електричної енергії державі за «зеленим» тарифом; підвищити конкурентоздатність та привабливість сільської оселі як об'єкта туристичного бізнесу; наблизити стандарти сільської гостинності до загальноприйнятих стандартів готельно-ресторанного сервісу; покращити рекреаційну облаштованість осель та об'єктів туристичної діяльності; дає можливість розвивати та відкривати об'єкти екологічного туризму в місцях значно віддалених від населених пунктів на «дикій» природі та створити там комфортні умови для відпочинку та проживання туристів.

\section{Список використаних джерел}

1. Про встановлення «зелених» тарифів на електричну енергію для приватних домогосподарств. Постанова Національної комісії, що здійснює державне регулювання у сфері енергетики від 28.12.2018 р. № 2071. URL : http://www.nerc.gov.ua/?id=37720 (дата звернення: 14.03.2019).

2. Корінний B.I. Іллінецька астроблема - геологічний феномен Вінниччини. Наукові записки Вінницького державного педагогічного університету імені Михайла Коиюбинського. Серія «Географія». Випуск 26. 2014. C. $170-174$.

3.Биркович B.I. Сільський зелений туризм - пріоритет розвитку туристичної галузі України. Стратегічні пріоритети. 2011. №1 (6). С. 138-143.

4.Власенко I.В. Передумови розвитку сільського зеленого туризму у Вінницькій області. Збалансоване природокористування. 2017. №2. С.42-47.

5.Столярчук П. Аналіз європейського досвіду організації сільського зеленого туризму та його категоризації. Вимірювальна техніка та метрологія. 2010. Вип. 71. С.175-184.

6.Компанія Солартех. ULR: https://solar-tech.com.ua (дата звернення: 10.03.2019). 
7. Компанія ЕкоХата. ULR: https://ecoxata.com.ua/ (дата звернення: 3.03.2019).

8.ПП «Правильне електроживлення». ULR: https://prel.prom.ua/g1317082sonyachni-batareyi-obladnannya (дата звернення: 05.04.2019).

9. Інтернет магазин електротехніки 220 VOLT. ULR: https://220volt.com.ua/solnechnye_stancii.htm (дата звернення: 12.03.2019).

\section{Reference}

1. Pro vstanovlennya «zelenykh» taryfiv na elektrychnu enerhiyu dlya pryvatnykh domohospodarstv: Postanova Natsional'noyi komisiyi, shcho zdiysnyuye derzhavne rehulyuvannya u sferi enerhetyky vid 28.12.2018 r. №2071. [On setting green tariffs for electric energy for private households: Resolution of the National Commission that carries out state regulation in the field of energy from 28.12.2018 № 2071]. www.nerts.gov.ua. Retrieved from http://www.nerts.gov.ua/?id=37720 (data zvernennya: 14.03.2019).

2. Korinnyy, V.I. (2014). Illinets'ka astroblema - heolohichnyy fenomen Vinnychchyny [Illinetsky astroblem - the geological phenomenon of Vinnytsya]. Naukovi zapysky Vinnyts'koho derzhavnoho pedahohichnoho universytetu imeni Mykhayla Kotsyubyns'koho Seriya «Heohrafiya» - Scientific Notes of the Vinnytsia State Pedagogical University named after Mikhail Kotsiubynsky Series Geography, 26, 170-174. [in Ukrainian].

3. Byrkovych; V.I. (2011). Sil's'kyy zelenyy turyzm - priorytet rozvytku turystychnoyi haluzi Ukrayiny [Rural green tourism - the priority of the development of the tourist industry of Ukraine]. Stratehichni priorytety. Naukovo-analitychnyy shchokvartal'nyy zbirnyk - Strategic priorities. Scientific and analytical quarterly collection, 1 (6), 138-143. [in Ukrainian].

4. Vlasenko, I.V. (2017). Peredumovy rozvytku sil's'koho zelenoho turyzmu u Vinnyts'kiy oblasti [Prerequisites for the development of rural green tourism in Vinnytsia region]. Zbalansovane pryrodokorystuvannya - Balanced Nature Use, Kyyiv, 2, 42-47.

5. Stolyarchuk, P., \& Dominyuk, V. (2010). Analiz yevropeys'koho dosvidu orhanizatsiyi sil's'koho zelenoho turyzmu ta yoho katehoryzatsiyi [Analysis of the European experience in the organization of rural green tourism and its categorization]. Vymiryuval'na tekhnika ta metrolohiya - Measurement technology and metrology, 71, 175-184. [in Ukrainian].

6. Kompaniya Solartekh. Retrived from:.https://solar-tech.tsom.ua (data zvernennya: 10.03.2019)

7. Kompaniya EkoKhata. Retrived from:.https://ecoxata.com.ua (data zvernennya: 3.03.2019).

8. PP «Pravyl'ne elektrozhyvlennya». Retrived from: https://prel.prom.ua/g1317082-sonyachni-batareyi-obladnannya (data zvernennya: 05.04.2018). 
9. Internet mahazyn elektrotekhniky 220 VOLT. Retrived from: https://220volt.com.ua/solnechnye_stancii.htm (data zvernennya: 12.03.2019).

\title{
Відомості про автора
}

ДЗІСь Віктор Григорович - кандидат технічних наук, доцент кафедри математики, фізики та комп'ютерних технологій, Вінницький національний аграрний університет (21008, м. Вінниця, вул. Сонячна, 3, e-mail: dzisvg@gmail.com).

DZIS Victor - Candidate of Technical Sciences, Associate Professor, Department of Mathematics, Physics and Computer Technologies of Vinnytsia National Agrarian University (21008, м. Вінниця, 3, Soniachna St., e-mail: dzisvg@gmail.com).

ДЗИСЬ Виктор Григорьевич - кандидат технических наук, доцент кафедры математики, физики и компьютерных технологий, Винницкий национальный аграрный университет (21008, г. Винница, ул. Солнечная,3 e-mail: dzisvg@gmail.com).

\section{ЗОВНІШНЬОЕКОНОМІЧНА ДІЯЛЬНІСТЬ, ТОВАРНІ ПОТОКИ СУБ'ЄКТІВ ГОСПОДАРЮВАННЯ ТА ЇХ ІНФРАСТРУКТУРНЕ ЗАБЕЗПЕЧЕННЯ}

\author{
УДК 338.2 (430)
}

DOI: $10.37128 / 2411-4413-2020-3-8$

\author{
ЕКОНОМІЧНА МОДЕЛЬ \\ НІМЕЧЧИНИ ЯК ФАКТОР \\ СОЩАЛЬНОї \\ СТАБІЛЬНОСТІ \\ ЦИФРОВОГО \\ СУСПІЛЬСТВА
}

\author{
ДЖЕДЖУЛА О.М., \\ доктор педагогічних наук, професор, \\ завідувач кафедри математики, \\ фізики та комп'ютерних технологій, \\ Вінницький національний \\ аграрний університет \\ (м. Вінниця)
}

У статті висвітлюються результати аналізу економічної моделі Німеччини та ї̈ вплив на сочіальну стабільність суспільства в умовах глобалізації та розвитку цифррових технологій. Соціальна орієнтація та стійкість економіки Німеччини забезпечує високі стандарти життя населення за такими критеріями як рівень сочіального розшарування суспільства $i$ бідності, рівень безробіття й інфлячії, медичне обслуговування, забезпеченість продовольством, наявність розгалуженої інфраструктури, доступна та якісна освіта. Пріоритети економічної моделі Німеччини спрямовані на інвестиції у людський капітал, розвиток сочіально значущої економіки, подолання різниці у доходах багатих $i$ бідних верств населення. Виокремлено особливо впливові фактори, які забезпечують дієвість і перспективність економічної моделі Німеччини: інвестиції, наявність провідних ринків, інновацій у всіх галузях виробниџтва, діджиталізація у всіх 